\title{
Religion and Political Protest: A Cross-Country Analysis
}

\author{
Gizem Arikan \\ Department of Political Science \\ Trinity College Dublin \\ 2-3 College Green \\ Dublin 2, Ireland \\ Phone: (353) - 1- 8961100 \\ arikang@tcd.ie
}

Pazit Ben-Nun Bloom

Department of Political Science

The Hebrew University of Jerusalem

Mount Scopus, Jerusalem, 91905 Israel

Phone: (972) - 02 - 5883162

Pazit.BenNun@mail.huji.ac.il

Forthcoming in Comparative Political Studies. 
Abstract: We argue that religion's effect on individual tendency to engage in political protest is influenced both by the resources available to citizens at the individual level and opportunities provided to religious groups and individuals at the country level. Combining data from last two waves of the World Values Surveys with aggregate data on religious regulation, we show that at private religious beliefs reduce an individual's protest potential while involvement in religious social networks fosters it. At the country level, we find that government regulation of religion decreases individual tendency to protest, and has an especially detrimental effect on the likelihood of religious minorities joining peaceful protest activities. These findings are in line with opportunity structure theories that stress the importance of system openness for fostering political protest. 


\section{Introduction}

The contribution of religious groups to some of the recent large-scale protests such as the Arab Spring has raised the question of religion's role in fostering collective political action (Hoffman \& Jamal, 2014). In fact, there is a long tradition of religious communities engaging in political activism (Djupe \& Gilbert, 2006, 2009) despite the conventional wisdom that emphasizes the system-justifying aspect of religiosity (Jost et al., 2014). What makes religion a facilitator of political protest and under which circumstances does religion become a passive force? We suggest that the effect of religion on political protest depends on both individual and system-level resources and opportunities. At the individual level, we hypothesize that involvement in religious social activities increases protest participation due to its effects on social capital development, identity-building, and the mobilizing potential of religious leadership. In contrast, we predict that religious belief diminishes the individual tendency to protest due to its association with tradition and conformity values.

At the system level, we argue that opportunities provided to religious groups and organizations foster individual protest participation (Eisinger, 1973; Meyer, 2004; Tarrow, 1994; Vráblíková, 2016). Our argument is built on Religious Economy Theory (RET), which posits that lower levels of state regulation of religion increase competition among religious organizations, which in turn facilitates the overall consumption of religion in society (Finke \& Stark, 1988; Iannaccone, 1991; Stark \& Finke, 1988, 2000; Stark \& Iannaconne, 1994). Accordingly, we expect the freedom and autonomy granted to religious institutions to provide an environment conducive to protest mobilization by religious groups and leaders, increasing overall individual tendency to protest. In contrast, regulation and restriction of religious activities decreases protest potential, especially among those who belong to minority religious traditions in a country. 
We test our hypotheses using multilevel modeling on data combined from the most recent versions of the World Values Surveys (Waves 5 and 6) with the Religion and State (RAS) dataset Round 3, and Pew Research data on religious regulation and restrictions. In addition to establishing the positive effects of religious social behavior at the individual and religious deregulation at the system levels, our results also show that those belonging to minority religious traditions are more likely to protest when religious organizations are deregulated and religious minorities are not restricted or discriminated against. These findings support opportunity structure approaches that stress the importance of system openness in facilitating protest.

Our work contributes to the current literature by providing a comprehensive theoretical framework that explains the relationship between religion and protest behavior at both individual and system levels. With some exceptions, the comparative literature on religion and protest has generally focused on a single dimension of individual religious experience and has not taken into account the effect of broader religious context. The finding that the effects of individual-level religiosity dimensions are often conditional on regulation of religion suggests that researchers must consider context to understand the relationship between religion and protest in a comparative framework.

\section{Religiosity as an Individual Resource}

In line with the literature, we define political protest as peaceful political activities that keep some distance from the political system while aiming at influencing it indirectly, such as political consumerism, signing petitions, or attending lawful demonstrations (Marien, Hooghe, \& Quintelier, 2010; Norris, 2002). This contrasts with electoral participation, which includes political activities that are "more or less directly aimed at influencing the selection of governmental personnel and/or the actions they take" such as voting, campaign work, etc. 
(Verba, Nie, \& Kim, 1978, p. 1; also see Dalton, van Sickle, \& Weldon, 2010; Norris, 2002). Our individual-level explanation of religion's effect on political protest builds on Resource Mobilization Theory, which emphasizes the critical role that individual resources play in turning dissatisfaction and grievances into collective political action (Klandermans, 1984; McCarthy \& Zald, 1977). Tangible material resources (such as time, money, etc.) as well as civic skills, efficacy, and trust are cited as individual-level resources that are essential for transforming individual and group grievances into political action. Religiosity can also be seen as providing critical resources for aggrieved individuals to join in collective political acts (Djupe \& Gilbert, 2009). However, different elements of the religious experience may supply different resources to the individual. In fact, current research conceptualizes religiosity as a multidimensional construct consisting of belief, behavior, and belonging dimensions (BenNun Bloom, Arikan, \& Courtemanche, 2015; Grzymala-Busse, 2012; Jelen \& Wilcox, 2002; Wald \& Wilcox, 2006) and shows that different components of religious experience have different effects on individual political mobilization (Hoffman \& Jamal, 2014; Hoffman \& Nugent, 2017; Scheufele, Nisbet, \& Brossard, 2003).

We argue that the social behavior aspect of religiosity, which refers to participation in organized religious communities, places of worship, and religious social networks (Smidt, Kellstedt, \& Guth, 2009), has a positive effect on protest participation. First, attendance in communal religious activities contributes to political protest by making participants more likely to acquire civic skills (Djupe \& Gilbert, 2009; Jelen \& Wilcox, 2002; Norris \& Inglehart, 2004; Putnam, 2000). Second, religious networks also bring like-minded individuals together, and facilitate building shared identity and solidarity (Jamal, 2005; Putnam, 2000; Scheufele et al., 2003). Third, religious organizations and religious leaders play an important role in mobilization, making religious participation an important factor in protest. Religious organizations reward their members with "selective incentives" that are 
important in mitigating the collective action problems underlying political mobilization (Olson, 1965), such as salvation, spiritual well-being, and positively distinct social identity. In addition, regular and frequent meetings enable religious leaders to disseminate information to the masses (Djupe \& Gilbert, 2006; Wald, Silverman, \& Fridy, 2005, p. 135). Exposure to political information through engagement in religious communities increases the saliency of group interests for religious attendees (Hoffman \& Nugent, 2017), recruits the devout to politics, and forms political consciousness (Djupe \& Grant, 2001). Messages delivered from the pulpit also encourage participation by increasing internal efficacy (McClarendon \& Riedl, 2015).

In short, participation in communal religious activities helps individuals acquire the necessary skills and orientations to transform grievances into collective political action. We thus hypothesize that the social behavior component of religious experience is associated with increased political protest $(H 1)$.

The second dimension of religious experience is religious belief, which refers to the set of values and convictions associated with an understanding of the divine and humanity's relationship to it - such as a belief in God, heaven, hell, or life after death (Grzymala-Busse 2012, p. 427; Layman, 2001). Some scholars suggest that religious belief can inspire protest behavior. Since belief systems entail notions of justice, honesty, and caring about those in need, the devout may be more sensitive towards social and political injustices, corruption, and mismanagement, which this may make them more likely to participate in political protest (Hoffman \& Jamal, 2014; McVeigh \& Sikkink, 2001).

Nevertheless, we expect religious belief to generally reduce individual propensity to protest when the social behavior component of religious experience is held constant. This is because the effect of religious theology and religious values on political protest is often conditional on whether a religion's leadership interprets these teachings and values to inspire 
collective action. The scriptures and teachings of any religion can be interpreted to justify different ends, including political apathy, passivity, proactivity, or political violence (Philpott, 2007; Sandal, 2012). Studies on the Roman Catholic Church's involvement in the politics of democratization in Latin America (Gill, 1998) or on the centrality of religious doctrine in intrareligious conflicts involving Muslims (Fox, 2004), for example, suggest that religious organizations and leaders may adopt different sets of principles that may inspire or depress political activity at different times. Whether such changes at the religious elite level result from changes in political theology (e.g., Philpott, 2007) or in patterns of religious competition (e.g., Gill, 1998; Isaacs, 2017), they nonetheless suggest that a high level of devotion as of itself does not ensure that an individual or community will actively participate in politics (Philpott, 2007, p. 522; also see Collins, 2007).

We suggest that, all else being equal, the belief component of religiosity will generally serve to justify the status quo and depress political protest because religious belief is strongly connected to values that promote the conservation of social order, such as tradition and conformity to social rules and norms (Saroglou, Delpierre, \& Dernelle, 2004). These values emphasize acceptance of traditional norms and practices, and are associated with systemjustifying tendencies and a commitment to preserving the status quo (Jost et al., 2014). Unconventional political activities, on the other hand, often question the existing social and political order and aim at challenging the status quo. In fact, tradition and conformity values are negatively related to political activism (Schwartz, 2007). Thus, holding constant the effect of religious social behavior, we hypothesize that the belief dimension of religiosity has a negative effect on political protest $(H 2)$.

The third aspect of religiosity is identification as a member of a particular organized denomination, movement, or trend within a denomination, typically referred to as one's belonging (Layman, 2001). So far, most debate in the literature concerning the effect of 
belonging on political protest has focused on the question of whether or to what extent the specific denomination or tradition that an individual belongs to affects her tendency to protest (Djupe \& Grant, 2001; Hoffman \& Jamal, 2014). Here, we focus on the effect of the minority or majority status of the religious tradition that an individual belongs to rather than the effect of belonging to a specific religious tradition.

The current literature offers theoretical rationales for supporting either a positive or a negative relationship between minority status and protest. On the one hand, religious minorities often experience discrimination, which may give rise to shared grievances that in turn leads them to organize around these grievances and engage in collective political acts (Gurr 1993, 2000; Fox, 2002; Tilly 1978). In addition, the small size of minority religious groups may enable them to more easily develop group consciousness and solve collective action problems (Bobo \& Gilliam, 1990; Olson 1965). According to these explanations, the presence of collective grievances and group consciousness may make members of minority groups more likely to participate in political protest.

On the other hand, there is growing evidence that religious discrimination does not always lead to grievances (Fox, 2002; Fox, Bader, \& McClure, 2017; Wickham, 2002) and that grievances do not always lead to mobilization among religious minorities (Basedau, Fox, Pierskalla, Strüver, \& Vüllers, 2017; Fox, 2002; also see Gurr, 2000, pp. 13-15). Minority groups also need organization, resources, and political opportunities to turn grievances into action (e.g. Gurr, 1993, 2000; Tilly 1978, also see Fox 2002, 2004). That is, successful mobilization depends not only on grievances but also on the networks and on the efforts of leadership and movement members to motivate participation, generate resources, and take advantage of opportunities (Collins, 2007; Wickham, 2002). Minority group members may have fewer opportunities and resources for establishing these networks especially when system level opportunities are not open. We thus suggest that the effect of minority status on 
political protest would largely depend on the structure of opportunities at the system level and develop this interactive hypothesis in the next section.

\section{Religious Markets as Opportunity Structures}

The literature acknowledges the crucial role of political and social context in facilitating protest behavior (Klandermans, 1984; Tilly, 1978). The Political Opportunity Structure (POS) approach stresses the role of opportunities and incentives available to groups or individuals that affect their expectations and the risks or potential benefits of collective action in fostering political protest (Eisinger, 1973; Meyer, 2004; Tarrow, 1994). Open political systems that enable citizens and groups to make demands and criticize government actions without fear of reprisal reduce the risks and costs associated with engaging in protest, thereby facilitating collective political action (Eisinger, 1973). In fact, there is growing crossnational evidence that more open and democratic environments are more conducive to protest activity (Dalton et al., 2010; Vráblíková, 2016; Welzel \& Deutsch, 2012). While many types of political opportunities exist, we highlight the role of religious freedom in facilitating political protest. We build on Religious Economy Theory (RET) to formulate our hypothesis that freedom of religion increases political protest whereas regulation of religion by the government reduces it, and identify two key mechanisms for this process: (1) decreasing mobilization potential due to reduced competition between religious groups and organizations, and (2) decreasing levels of religious adherence.

Starting with the first mechanism, analogous to free market economics, RET suggests that unregulated religious markets lead religious organizations to compete for followers, which makes them offer more appealing products (Finke \& Stark, 1988; Gill, 1998, 2008; Stark \& Finke, 2000). Since consumers are "most apt to respond to religions that make the most effective efforts to enlist them," (Stark \& Finke 2000, p. 36) competition in the religious 
market in the absence of state regulation creates "eager and efficient suppliers of religion" (Stark \& Finke 2000, p. 36) willing to tailor their product to the demands of potential followers. As a result, RET predicts religious freedom to lead to greater competition among religious organizations for adherents - a process that motivates various religious groups or organizations to cater to the special interests of specific groups (Finke \& Stark, 1988, p. 42; Finke, 2013; also see Gill, 1998). Under such competition, we might expect religious leadership to have more incentives to become politically involved in and actively defend the interests of their community in order to increase their outreach (Ben-Nun Bloom, 2016; BenNun Bloom, Arikan \& Sommer, 2014; Gill, 2008).

Anecdotal evidence supports the expectation that religious groups and organizations respond to the opportunity structures created by competitive religious markets by becoming more politically involved. For example, religious groups in Chile, especially Protestants, became more active when opportunities opened up after the end of Pinochet's dictatorship (Steiganga \& Coleman, 1995, p. 480; quoted in Wald, Silverman, \& Fridy, 2005). Likewise, Mexico's Catholic Church started to become a visible political player in the late 1970s after harsh constitutional laws against the clergy and church activity were relaxed (Wald, Silverman, \& Fridy, 2005). Religious organizations in competitive religious markets not only defend the interests of religious groups but also mobilize communities for secular causes. For example, the competition that the Catholic Church faced from Protestant denominations in Latin America led the Church to promote secular ethnic mobilization (Trejo, 2009) and adopt a more progressive stance to increase its appeal among the poor (Gill, 1998). Similarly, the clergy's active support for the civil rights movement is partly attributed to the incentives provided by the high level of religious market competition in the United States (GrzymalaBusse, 2012). Thus, in more competitive markets, we expect religious leaderships to be more active and more likely to mobilize their communities than in religiously regulated markets. 
The second mechanism through which religious freedom increases protest potential is through increased religious adherence. According to RET, greater competition among religious organizations raises the supply of religion, which leads to higher levels of religious consumption (Gill, 2008; Stark, \& Finke, 1988; for cross-national evidence, see Fox \& Tabory, 2008). Greater levels of religious social activity means more individuals develop the skills and resources necessary for protest participation, thereby increasing the mobilizing potential of religion. Skills acquired via religious social activities may also be utilized for political activities outside the religious networks, increasing overall levels of political participation (Peterson, 1992). Thus, the second implication of free religious markets that we identify as relevant for increasing overall levels of political protest is via increased skills and social capital as a result of higher levels of religious participation.

We therefore expect unregulated religious markets to provide opportunities and incentives that increase protest potential. Conversely, as religious regulation increases, religious leaders have fewer incentives and organizational resources to become involved in politics and mobilize the masses for political action (Gill, 2008). Government control of religion shrinks religious civil society and leaves religious communities with fewer opportunities and resources to organize or govern themselves (Sarkissian, 2015). Regulations and restrictions on public speeches and gatherings, clerical hiring, religious publications and sermons make it harder for a religion's leaders to organize their community around shared interests (Sarkissian, 2015). This also leads to decreased commitment, which reduces the political influence of religious institutions and leaders. Under strict government regulation, religious organizations influence fewer people because they lose some of their symbolic and organizational resources. Accordingly, we hypothesize that religious regulation has a negative effect on political protest (H3). 
In addition to its direct effect on individual protest potential, we also expect government regulation of religion to moderate the relationship between individual religious resources and protest participation. First, we expect those who are already involved in religious social networks have more opportunities to protest when religious markets are deregulated. As mentioned above, open religious environments create more incentives for religious leaderships to mobilize their constituencies. This creates more possibilities for protest for those who are already involved. Conversely, religious regulation decreases the incentives and potential for mobilization by religious leaders and organizations. Thus, members of such organizations may have fewer opportunities and/or motivation to take part in collective political actions. Accordingly, we hypothesize that religious regulation weakens the positive effect that religious social behavior has on political protest (H4).

Second, we expect religious regulation to moderate the effect of minority status on political protest. We suggest that regulated religious markets provide minorities with fewer opportunities to organize as groups, form networks, and increase group consciousness. Religious organizations are usually the most stable institutions representing minorities (Fox, 2004). When governments regulate religious markets and restrict or monitor religious institutions, leaders, and religious practices, or intimidate religious organizations and their leaders, there will be fewer opportunities for minority group members to mobilize around shared interests or grievances. Increased regulation, by allowing less autonomy and freedom to minority religious groups, may increase the risks associated with protest, thus decreasing the likelihood that members of minority traditions will engage in protest. ${ }^{1}$ As a result, we

\footnotetext{
${ }^{1}$ Furthermore, religious regulation is associated with greater intolerance of religious minorities (Helbling \& Traunmüller, 2016), making majority-minority cooperation concerning attaining common political goals less likely. Thus under high government
} 
hypothesize that religious regulation decreases the effect of minority status on political protest (H5).

\section{Data and Variables}

The individual level data came from the latest two waves of the World Values Surveys (WVS). We used all countries available in the sixth wave that was collected between 2010 and 2014, and added countries that were available in the fifth wave but were excluded from the sixth. A major advantage of the sixth wave of WVS is that it covers a wide range of nonWestern (and especially Muslim) countries that were not included in earlier waves. By adding countries from the fifth wave, which included a wider range of countries from Western and Eastern Europe, we significantly increased our degrees of freedom at the country level and obtained a dataset with a more diverse set of countries. Online Appendix 1 includes the full list of countries along with country scores on the key country-level variables.

Although WVS has been conducted since the 1980s, the earlier waves did not include many countries. For example, Wave 1 included data from only 10 countries while Wave 2 included only 18 countries. Many non-Western countries were largely absent until the Wave 4, which was collected between 2000 and 2004, and even then, the number of non-Western cases was much lower than in later waves. As a result, we were unable to exploit the timeseries dimension of WVS and have restricted our analyses to a single point in time.

Our measure of protest participation is an additive index of three items (see Dalton et al., 2010; Norris, 2002; Vráblíková, 2016). In line with common practice in the literature, we used an index rather than inspecting each item separately because we wanted to increase

regulation, religious minorities may have to rely on their own communal resources to engage in collective political acts. 
variance in the dependent variable and obtain a more robust summary measure. In addition, Dalton et al. (2010, p. 12) compared the national scores of the protest index generated from the WVS items with a measure of civil domestic conflict and found a reasonable correlation between the two measures, providing evidence in favor of the validity of an additive index of political protest. Finally, since many prominent studies in the literature employ an index of political protest rather than the separately examining each action, this strategy allows us to directly compare the substantive results with those of previous studies.

The WVS asked respondents whether they took part, might take part, or would never involve themselves in different forms of non-electoral protest activities: signing petitions, attending lawful demonstrations, or participating in boycotts. ${ }^{2}$ For each of the three items, those who have already engaged in these actions are coded 1; those who indicated that they might are coded 0.5; and those who indicated they would never engage in this type of action receive a score of 0 . This coding approach is similar to the one adapted by Welzel and Deutsch (2012). They suggest that, since survey responses are "reported" rather than "observed" actions, a respondent choosing the "have done" category might simply be reporting a stronger predisposition to engage in political protest rather than reporting an actual past engagement. Nevertheless, even if the respondent did not engage in such an act, the response indicates a stronger predisposition to participate in protest than opting for the "might do" category. The "might do" category should receive more weight than the "would never do" option since it still indicates a stronger tendency than completely refusing to partake in an action (Welzel \& Deutsch, p. 470). In addition, we suggest that, since engaging in protest depends partly upon "the structure of opportunities generated by particular issues, specific

\footnotetext{
${ }^{2}$ Although there are other items available in both waves, due to differences in wording across different waves, we chose not to include them in the protest index.
} 
events, and the role of leaders," (Norris, 2002, p. 194) it is possible that a respondent who opts for the "might do" category has not yet engaged in an act of protest because she did not come across any opportunities. This should especially be the case in autocratic political regimes, where channels for political mobilization are restricted. Moreover, in such systems, even engaging in very common forms of protest activity like signing petitions may pose risks (see for example, Bohannon, 2016). Thus, assigning a medium score to respondents who choose the "might do" option allows us to capture the level of their propensity to engage in political protest, even if they did not find the opportunity to do so. At the same time, it allows us to distinguish these respondents from those who devoted time and resources to take part in protest activities. Our final index score was re-scaled to the interval between 0 and 1 , where higher values indicate a higher propensity to engage in protest. $^{3}$

Figure 1 presents the mean levels of protest tendency for countries included in our dataset. The values range from 0.05 to 0.6 . As might be expected, the lowest levels of political protest tendency are observed in countries with closed political structures, such as Azerbaijan (0.05), Malaysia (0.07), Kazakhstan (0.09), and Kyrgyzstan (0.011). Not surprisingly, mean levels of political protest are highest in some of the most democratic countries, such as New Zealand, Sweden, Norway, Switzerland, Australia, Italy, Canada, and France.

\footnotetext{
${ }^{3}$ Rescaling variables to vary $0-1$ is a standardization technique, which allows comparing the effect size of independent variables of different units. It is computed using the formula New value $=($ value $-\min ) /(\max -\min )$, which allows variables to have differing means and standard deviations but equal ranges.
} 


\section{Figure 1. Mean Levels of Protest Tendency}

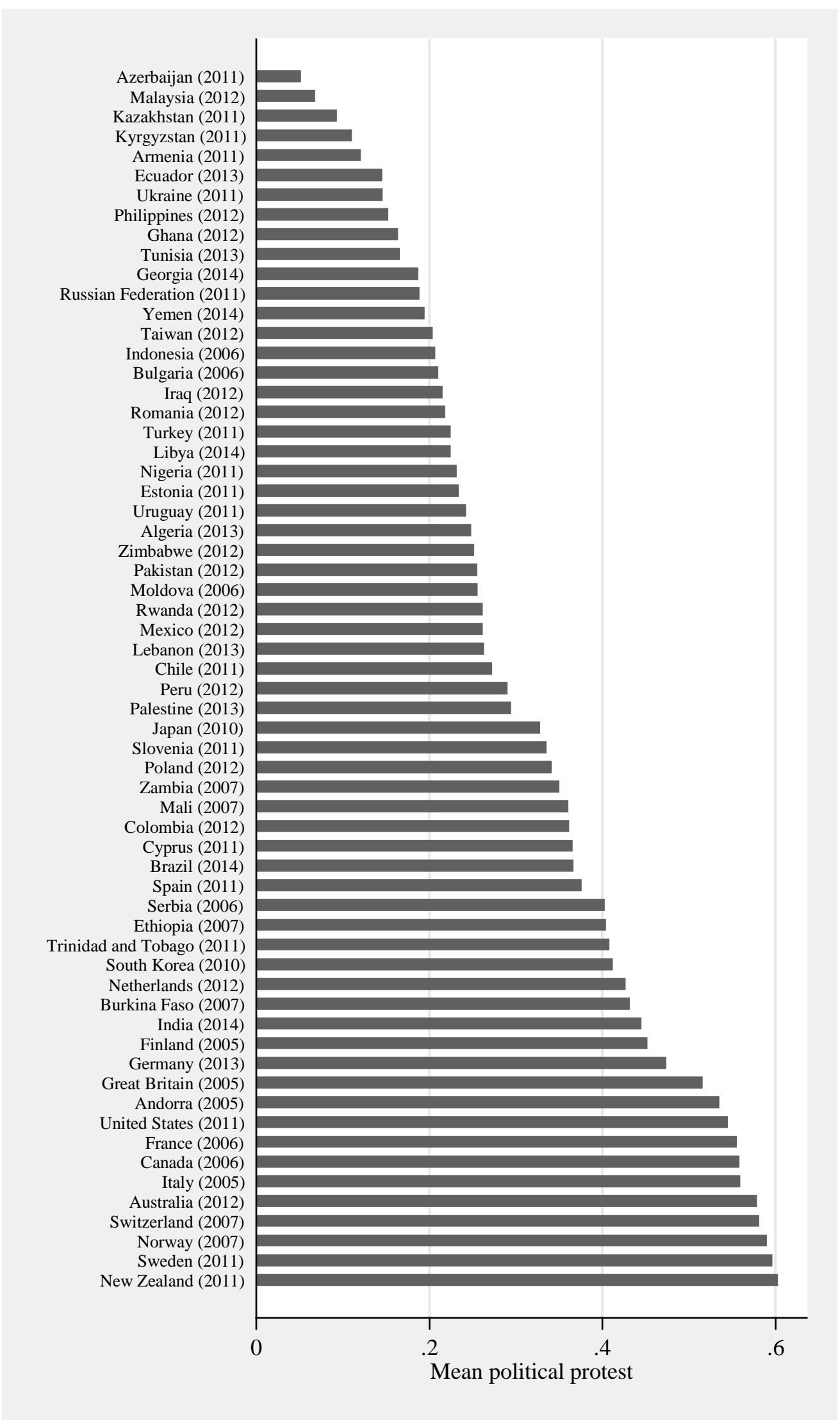


To measure religious belief, we constructed an additive index from the two items available in both waves: whether the respondent considers herself a religious person (1=yes, $0=$ no $)$, and the importance of God in the respondent's life $(10=$ very important, $1=$ not important at all) (Ben-Nun Bloom \& Arikan, 2012, 2013). ${ }^{4}$ We acknowledge that this measure may not necessarily reflect all the components of religious belief discussed above. However, unlike the earlier waves, Waves 5 and 6 have far fewer items that tap into the strength of religious beliefs. Nevertheless, we suggest that there is enough evidence from previous research supporting the validity of this simple additive measure of religiosity. For example, Ben-Nun Bloom and Arikan (2013, p. 385-386) compared the same two-item additive index constructed from Wave 5 data with a religious belief measure constructed using the larger number of items available in Wave 4. This latter measure included items such as belief in God, life after death, and heaven, the importance of God in the respondent's life, and getting comfort and strength from religion, and controlled for differential item functioning, which might obstruct the comparability of the construct across countries (Van de Vijver, 2003). The authors found a very strong correlation between the two measures constructed using different items ( $\mathrm{r}=0.89)$, suggesting that the simple additive measure performed substantively well. Marina Voicu (2012) also used a similar approach, testing for measurement invariance in religious belief items in 16 European countries in Wave 4 of the WVS dataset. Her analysis shows that measurement variance is less of a problem in the subset of countries that she analyzed. She also found the importance of God to be the strongest component of her religious belief index ( $\mathrm{r}=0.89$ between the index and the item), showing that this single item is a crucial component of religious belief. We are therefore confident that there is enough evidence for the validity of our religious belief index.

\footnotetext{
${ }^{4}$ Both items carry equal weight.
} 
Religious social behavior is an additive index of the frequency of attending religious services (an eight-category variable) and being an active/inactive member of a religious organization. ${ }^{5}$ When building the index, we gave a score of 1 to active members and a score of 0.5 to inactive members. Our reasoning for giving a value of 0.5 to inactive members was that, even if these respondents report being currently inactive in religious organizations, they might have been active in these organizations in the past and developed the civic skills necessary for collective mobilization. In addition, simply being a member of a religious organization may be an indicator of being more involved in religious social networks than someone who is not. Nevertheless, we reran the models with a revised version of the index in which inactive membership was coded as 0 (thus, being treated the same as no membership) and found that the results presented in Tables 1 and 2 were fully replicated. ${ }^{6}$

To code the minority status of respondents, we first recoded the sectarian or denominational subcategories in our dataset as nine main religious traditions (see Online Appendix 2 for details). We then consulted Barro's religious adherence dataset (Barro, 2003) and the CIA World Factbook to code the respondents as having minority status if the religious tradition they adhere to was different to the majority tradition in their country. That is, respondents who identified with the religious tradition that had the most adherents in a country were coded as having majority status while the rest were coded as a minority. Online Appendix 3 presents the list of religious traditions that were coded as the majority in each country.

We used two alternative measures for religious regulation from two datasets: the Religion and State (RAS) dataset Round 3 (RAS 3) and the Pew Research Center measures on

\footnotetext{
${ }^{5}$ The items carry equal weight.

${ }^{6}$ The results are available from the authors.
} 
global restrictions on religion. Both datasets contain information about different dimensions of religious regulation and freedom. RAS 3 data is matched with the survey year but the Pew data was not available for all years. For countries for which the available Pew data does not match the survey year, we used scores from the closest year available. For example, 2013 Pew scores were used for countries for which the survey year was 2014.

The religious regulation and restrictions measure in the RAS 3 dataset captures the extent to which the state regulates either all religions or the majority religion, and indicates "a fear, hatred, or suspicion of religion in general" (Fox, 2015). The measure is composed of items that tap various religious restrictions that governments may place on the majority or all religions, including but not limited to restrictions on religious and political parties and formal religious organizations; arrest, detention, or official harassment of religious figures and officials; restrictions on the public observance of religious practices, public religious speech, publication, or dissemination of written religious material. This measure thereby captures the extent to which the government is averse towards religious activity by clergy and religious groups. The index includes 29 types of restrictions and ranges from 0 (no government regulation) to 87 (maximum level of government regulation) although the maximum level of government regulation in our dataset is 46 (Azerbaijan).

The Pew dataset also identifies a dimension of religious freedom that is conceptually very similar to the RAS religious regulation measure: Government regulation of religion $(G R I)$ is defined as "the restrictions placed on the practice, profession, or selection of religion by the official laws, policies, or administrative actions of the state," thus representing the official rights and policies promoted by the state (Grim \& Finke, 2006, p. 7). This includes interfering with the right to worship, legal codes, and policy actions on religion, and the regulation of mission work, proselytizing, preaching, and conversion. The original index 
ranges from 0 to 10 while the highest level of the Pew GRI index in our dataset is 7.6 (Malaysia).

As might be expected, the Pew GRI and RAS regulation measures are highly correlated ( $\mathrm{r}=.71$ for our dataset). The main difference between the two measures is that the Pew GRI is a composite measure of government favoritism of religion, religious regulation, and discrimination against minority religious whereas the RAS dataset has separate measures for these concepts. This is why, we also considered RAS religious discrimination against minority religions measure to test our hypothesis concerning the conditional effect of religious regulation and restrictions on the effect of minority status on political protest (as per H5). While RAS religious regulation measure captures the restriction and regulation of religious activities for all religious groups, minority discrimination variable concerns the restrictions on religious institutions and leadership, and limitations over religious activities directed towards minority religious groups specifically (Fox, 2015, 2016). This measure includes 36 types of restrictions and regulations that the governments place on the practice of religion by minority religious groups. ${ }^{7}$ The original index ranges from 0 to 108 . The Russian Federation has the highest index value in our dataset with a score of 48 , followed by Pakistan with a score of 43 .

All the models controlled for a number of individual-level variables including age, gender, income level, low and middle education dummies, ideological orientation,

\footnotetext{
${ }^{7}$ These include restrictions on religious practices by minority groups, restrictions on religious institutions and clergy, restrictions on conversion to minority religions and their proselytizing activities, and other restrictions, including but not limited to mandatory education in majority religion, declaration of some minority religions as dangerous sects, and state surveillance of minority religious activities.
} 
organizational membership (coded 1 if the respondent is a member of at least one secular social organization, 0 otherwise), life satisfaction, satisfaction with the household's financial situation, interpersonal trust, and interest in politics. We recoded all individual level key and control variables with the exception of age to vary between 0 and 1 . We also controlled for the effect of overall openness of political structures (Polity IV scores) and socioeconomic development (logged GDP per capita, PPP) at the country level. Scores for both variables are those that match the year in which surveys were conducted. Summary statistics for all individual and country-level variables are presented in Online Appendix 4.

The data consists of individual respondents nested in countries. Due to the hierarchical structure of the data, we employed multilevel modelling as ignoring the clustering of data would lead to attenuated standard errors (Steenbergen \& Jones, 2002). ${ }^{8}$ In the first set of models where we tested for the independent effects of individual-level religiosity dimensions and country-level religious regulation, we used random intercept models that model variances at the individual and country levels. In the next set of models, where we tested for the effects of religious social behavior and minority status conditional on levels of country-level religious regulation, we specified random slope models with cross-level interactions.

\footnotetext{
${ }^{8}$ Before the full models, we first ran random effects ANOVA to determine what percentage of the variance in individual-level protest behavior was due to cross-national differences. The LR test rejected the null hypothesis that the fit of the random-effects model was equal to that of an ordinary regression with a constant, while the intra-class correlation was.37, suggesting that 37 percent of the variance in individual-level political participation is explained by country-level factors. This provides further justification for using a multilevel model.
} 


\section{Results}

Main effects of individual level religious resources on protest. Table 1 presents the results of the random intercept models that test for the effects of individual-level religious resources and religious market variables on political protest. While Model 1.1 does not specify any country-level predictors, Models 1.2 and 1.3 test for the effect of the Pew GRI and RAS religious regulation measures. Models 1.4 and 1.5 also control for the effects of level of democracy and socioeconomic development. All the models in Table 1 provided strong empirical support for $\mathrm{H} 1$ and $\mathrm{H} 2$. In line with $\mathrm{H} 1$, we found that religious social behavior increases the tendency to engage in political protest, as manifested by the positive and statistically significant coefficient for this variable. Moreover, as predicted by $\mathrm{H} 2$, religious belief has the opposite effect of decreasing protest potential. Thus, the results present a strong case for the differential effects of the two religiosity dimensions and for the crucial effect of religious social behavior in increasing an individual's tendency to protest. While internal religiosity, measured as the intensity of devotion to fundamental religious convictions decreases individual tendency to engage in political protest, sustained participation in religious social networks increases it. 
Table 1. Religiosity, Religious Regulation, and Political Protest: Random

\section{Intercept Models}

\begin{tabular}{|c|c|c|c|c|c|}
\hline & Model 1.1 & Model 1.2 & Model 1.3 & Model 1.4 & Model 1.5 \\
\hline Intercept & $\begin{array}{l}.383 \\
(.019)^{* *}\end{array}$ & $\begin{array}{l}.495 \\
(.027)^{* *}\end{array}$ & $\begin{array}{l}.457 \\
(.021)^{* *}\end{array}$ & $\begin{array}{l}.159 \\
(.137) \\
\end{array}$ & $\begin{array}{l}.148 \\
(.136) \\
\end{array}$ \\
\hline \multicolumn{6}{|l|}{ Individual-Level Effects } \\
\hline Gender (male $=1)$ & $\begin{array}{l}.016 \\
(.002)^{* * *}\end{array}$ & $\begin{array}{l}.016 \\
(.002)^{* * *}\end{array}$ & $\begin{array}{l}.016 \\
(.002)^{* *}\end{array}$ & $\begin{array}{l}.014 \\
(.002)^{* *}\end{array}$ & $\begin{array}{l}.014 \\
(.002)^{* *}\end{array}$ \\
\hline Age & $\begin{array}{l}-.000 \\
(.000) * *\end{array}$ & $\begin{array}{l}-.001 \\
(.000)^{* *}\end{array}$ & $\begin{array}{l}-.001 \\
(.000) * *\end{array}$ & $\begin{array}{l}-.001 \\
(.000)^{* *}\end{array}$ & $\begin{array}{l}-.001 \\
(.000) * *\end{array}$ \\
\hline Low education (dummy) & $\begin{array}{l}-.105 \\
(.003)^{* *}\end{array}$ & $\begin{array}{l}.105 \\
(.003)^{* *}\end{array}$ & $\begin{array}{l}.105 \\
(.003)^{* *}\end{array}$ & $\begin{array}{l}-.105 \\
(.003)^{* *}\end{array}$ & $\begin{array}{l}.105 \\
(.003)^{* *}\end{array}$ \\
\hline Medium education (dummy) & $\begin{array}{l}-.063 \\
(.003)^{* *}\end{array}$ & $\begin{array}{l}-.063 \\
(.003)^{* *}\end{array}$ & $\begin{array}{l}.063 \\
(.003)^{* *}\end{array}$ & $\begin{array}{l}-.064 \\
(.003)^{* *}\end{array}$ & $\begin{array}{l}-.064 \\
(.003)^{* *}\end{array}$ \\
\hline Income & $\begin{array}{l}.025 \\
(.005)^{* *}\end{array}$ & $\begin{array}{l}.025 \\
(.005)^{* *}\end{array}$ & $\begin{array}{l}.025 \\
(.005)^{* *}\end{array}$ & $\begin{array}{l}.023 \\
(.005)^{* *}\end{array}$ & $\begin{array}{l}.023 \\
(.005)^{* *}\end{array}$ \\
\hline Associational membership & $\begin{array}{l}.070 \\
(.003)^{* * *}\end{array}$ & $\begin{array}{l}.070 \\
(.002)^{* * *}\end{array}$ & $\begin{array}{l}.070 \\
(.002)^{* *}\end{array}$ & $\begin{array}{l}.070 \\
(.003)^{* *}\end{array}$ & $\begin{array}{l}.070 \\
(.003)^{* *}\end{array}$ \\
\hline Ideology & $\begin{array}{l}.078 \\
(.004)^{* *}\end{array}$ & $\begin{array}{l}-.077 \\
(.004)^{* *}\end{array}$ & $\begin{array}{l}.077 \\
(.004)^{* *}\end{array}$ & $\begin{array}{l}.077 \\
(.004)^{* *}\end{array}$ & $\begin{array}{l}.077 \\
(.004)^{* *}\end{array}$ \\
\hline Life satisfaction & $\begin{array}{l}.008 \\
(.005) \\
\end{array}$ & $\begin{array}{l}-.008 \\
(.005) \\
\end{array}$ & $\begin{array}{l}.008 \\
(.005)\end{array}$ & $\begin{array}{l}.007 \\
(.005) \\
\end{array}$ & $\begin{array}{l}-.007 \\
(.005) \\
\end{array}$ \\
\hline Satisfaction with financial situation & $\begin{array}{l}-.037 \\
(.005)^{* *}\end{array}$ & $\begin{array}{l}-.037 \\
(.005)^{* *}\end{array}$ & $\begin{array}{l}-.037 \\
(.005)^{* *}\end{array}$ & $\begin{array}{l}-.037 \\
(.005)^{* *}\end{array}$ & $\begin{array}{l}-.037 \\
(.005)^{* *}\end{array}$ \\
\hline Interpersonal trust & $\begin{array}{l}.021 \\
(.003)^{* *}\end{array}$ & $\begin{array}{l}.021 \\
(.003)^{* *}\end{array}$ & $\begin{array}{l}.021 \\
(.003)^{* *}\end{array}$ & $\begin{array}{l}.020 \\
(.003)^{* *}\end{array}$ & $\begin{array}{l}.020 \\
(.003)^{* *}\end{array}$ \\
\hline Interest in politics & $\begin{array}{l}.194 \\
(.003)^{* *}\end{array}$ & $\begin{array}{l}.195 \\
(.003)^{* *}\end{array}$ & $\begin{array}{l}.195 \\
(.003)^{* *}\end{array}$ & $\begin{array}{l}.194 \\
(.004)^{* *}\end{array}$ & $\begin{array}{l}.194 \\
(.004)^{* *}\end{array}$ \\
\hline Religious belief & $\begin{array}{l}-.021 \\
(.005)^{* *}\end{array}$ & $\begin{array}{l}-.022 \\
(.005) * * \\
\end{array}$ & $\begin{array}{l}-.022 \\
(.005)^{* *}\end{array}$ & $\begin{array}{l}-.020 \\
(.005)^{* *}\end{array}$ & $\begin{array}{l}-.020 \\
(.005)^{* *}\end{array}$ \\
\hline Religious social behaviour & $\begin{array}{l}.017 \\
(.005)^{* *}\end{array}$ & $\begin{array}{l}.017 \\
(.005)^{* *}\end{array}$ & $\begin{array}{l}.017 \\
(.005)^{* *}\end{array}$ & $\begin{array}{l}.016 \\
(.005)^{* *}\end{array}$ & $\begin{array}{l}.016 \\
(.005)^{* *}\end{array}$ \\
\hline Minority status & $\begin{array}{l}.005 \\
(.003)^{*}\end{array}$ & $\begin{array}{l}.005 \\
(.003)^{*}\end{array}$ & $\begin{array}{l}.005 \\
(.003)^{*}\end{array}$ & $\begin{array}{l}.005 \\
(.003) \\
\end{array}$ & $\begin{array}{l}.005 \\
(.003) \\
\end{array}$ \\
\hline Catholic & $\begin{array}{l}.021 \\
(.005)^{* *}\end{array}$ & $\begin{array}{l}.021 \\
(.005)^{* *}\end{array}$ & $\begin{array}{l}-.021 \\
(.005)^{* *}\end{array}$ & $\begin{array}{l}-.020 \\
(.005)^{* *}\end{array}$ & $\begin{array}{l}.020 \\
(.005)^{* *}\end{array}$ \\
\hline Protestant & $\begin{array}{l}-.020 \\
(.005)^{* *}\end{array}$ & $\begin{array}{l}-.020 \\
(.005)^{* *}\end{array}$ & $\begin{array}{l}-.020 \\
(.005)^{* *}\end{array}$ & $\begin{array}{l}-.021 \\
(.005)^{* *}\end{array}$ & $\begin{array}{l}-.021 \\
(.005)^{* *}\end{array}$ \\
\hline Independent & $\begin{array}{l}.014 \\
(.007)^{* *}\end{array}$ & $\begin{array}{l}.014 \\
(.007)^{* *}\end{array}$ & $\begin{array}{l}.014 \\
(.007)^{* *}\end{array}$ & $\begin{array}{l}.013 \\
(.007)^{*}\end{array}$ & $\begin{array}{l}.013 \\
(.007)^{*}\end{array}$ \\
\hline Evangelical & $\begin{array}{l}.028 \\
(.009)^{* *}\end{array}$ & $\begin{array}{l}-.028 \\
(.009)^{* *}\end{array}$ & $\begin{array}{l}.028 \\
(.009)^{* *}\end{array}$ & $\begin{array}{l}.027 \\
(.009) * *\end{array}$ & $\begin{array}{l}.027 \\
(.009)^{* *}\end{array}$ \\
\hline Orthodox & $\begin{array}{l}-.019 \\
(.006)^{* *}\end{array}$ & $\begin{array}{l}-.018 \\
(.006)^{* *}\end{array}$ & $\begin{array}{l}-.019 \\
(.006)^{* *}\end{array}$ & $\begin{array}{l}-.019 \\
(.007)^{* *}\end{array}$ & $\begin{array}{l}-.019 \\
(.007)^{* *}\end{array}$ \\
\hline Muslim & $\begin{array}{l}-.033 \\
(.007)^{* *}\end{array}$ & $\begin{array}{l}-.031 \\
(.007)^{* *}\end{array}$ & $\begin{array}{l}.031 \\
(.007)^{* *}\end{array}$ & $\begin{array}{l}-.030 \\
(.007)^{* *}\end{array}$ & $\begin{array}{l}-.030 \\
(.007)^{* *}\end{array}$ \\
\hline Buddhist & $\begin{array}{l}.002 \\
(.009)\end{array}$ & $\begin{array}{l}.002 \\
(.009)\end{array}$ & $\begin{array}{l}.002 \\
(.009)\end{array}$ & $\begin{array}{l}.001 \\
(.010)\end{array}$ & $\begin{array}{l}.001 \\
(.010)\end{array}$ \\
\hline Hindu & $\begin{array}{l}-.045 \\
(.012)^{* *}\end{array}$ & $\begin{array}{l}-.044 \\
(.012)^{* *}\end{array}$ & $\begin{array}{l}-.044 \\
(.012)^{* *}\end{array}$ & $\begin{array}{l}-.042 \\
(.013)^{* *}\end{array}$ & $\begin{array}{l}-.042 \\
(.013)^{* *}\end{array}$ \\
\hline Jewish & $\begin{array}{l}-.006 \\
(.014)\end{array}$ & $\begin{array}{l}.006 \\
(.014)\end{array}$ & $\begin{array}{l}-.006 \\
(.014)\end{array}$ & $\begin{array}{l}.010 \\
(.020)\end{array}$ & $\begin{array}{l}.010 \\
(.020)\end{array}$ \\
\hline
\end{tabular}


Table 1 (continued)

\begin{tabular}{|c|c|c|c|c|c|}
\hline & Model 1.1 & Model 1.2 & Model 1.3 & Model 1.4 & Model 1.5 \\
\hline \multicolumn{6}{|l|}{ Country-Level Effects } \\
\hline Pew GRI & - & $\begin{array}{l}-.036 \\
(.007)^{* *} \\
\end{array}$ & - & $\begin{array}{l}-.030 \\
(.007)^{* *}\end{array}$ & - \\
\hline RAS religious regulation & - & - & $\begin{array}{l}-.007 \\
(.001)^{* *}\end{array}$ & - & $\begin{array}{l}-.006 \\
(.002)^{* *}\end{array}$ \\
\hline Polity score & - & - & - & $\begin{array}{l}.005 \\
(.004)\end{array}$ & $\begin{array}{l}.003 \\
(.004)\end{array}$ \\
\hline GDP per capita (PPP, logged) & - & - & - & $\begin{array}{l}.030 \\
(.015)^{*}\end{array}$ & $\begin{array}{l}.029 \\
(.015)^{*}\end{array}$ \\
\hline \multicolumn{6}{|l|}{ Variance Components } \\
\hline Random intercept variance & $\begin{array}{l}.135 \\
(.012) * *\end{array}$ & $\begin{array}{l}.114 \\
(.010) * *\end{array}$ & $\begin{array}{l}.111 \\
(.010) * *\end{array}$ & $\begin{array}{l}.104 \\
(.010)^{* *}\end{array}$ & $\begin{array}{l}.103 \\
(.010)^{* *}\end{array}$ \\
\hline Residual variance & $\begin{array}{l}.242 \\
(.001)^{* *}\end{array}$ & $\begin{array}{l}.242 \\
(.001)^{* *}\end{array}$ & $\begin{array}{l}.242 \\
(.001)^{* *}\end{array}$ & $\begin{array}{l}.241 \\
(.001)^{* *}\end{array}$ & $\begin{array}{l}.250 \\
(.001)^{* *}\end{array}$ \\
\hline \multicolumn{6}{|l|}{ Model Fit Indices } \\
\hline Wald chi ${ }^{2}$ & 7981.99 & 8016.36 & 8021.53 & 7495.33 & 7496.19 \\
\hline$-2 \times$ Log Likelihood & 299.18 & 277.41 & 274.75 & -94.66 & -94.99 \\
\hline N. Level-1 Units & 56837 & 56837 & 56837 & 53430 & 53430 \\
\hline N. Level-2 Units & 62 & 62 & 62 & 58 & 58 \\
\hline
\end{tabular}

Non-standardized coefficients with standard errors in parentheses. $* p<0.1$ (two-tailed), ** $p<0.05$ (two-tailed).

Note that the predicted effect of both dimensions on protest potential was substantively very close but in opposite directions. When we re-ran the analysis in Model 1.4 with religious belief and religious social behavior combined into an additive index of overall religiosity, we found null effects $(b=-.002, p=.391)$. This suggests that ignoring the multidimensionality of religious experience by combining the belief and social behavior dimensions into a single measure of religiosity leads to null findings. The fact that different researchers have employed different strategies to measure religiosity may thus be one reason for some inconsistent findings concerning religiosity's effect on political protest.

Our results also reveal that, after controlling for an individual's level of belief and social religious behavior, identification with a major religious tradition has either a negative or null effect on protest activity, compared to the baseline of no affiliation with a religious 
denomination. We also investigated whether strength of religious belief, extent of participation in religious social networks, or minority status moderated the effect of belonging by specifying interactions between these variables and the respondent's religious identification. With the exception of Muslim identification, we found no evidence that the effects of identification with major religious traditions differ significantly for levels of religious belief, religious social behavior, and minority status. Thus, the negative and independent effects of Protestant, Roman Catholic, Orthodox, Hindu, independent, and Evangelical identifications, and the null effects of Buddhist and Jewish identifications are generally retained when taking into account the potential moderating effects of other religiosity variables. Results and discussion of these additional analyses are presented in Online Appendix 5.

The coefficient for the minority status variable was positive and achieved marginal statistical significance $(\mathrm{p}<.10)$ in Models $1.1-1.3$ but became statistically null when overall political openness and socioeconomic development were controlled for (Models 1.4 and 1.5). As discussed in the previous sections, these null results may stem from the fact that the effect of minority religious status on political protest is conditional on the opportunities and resources available to religious groups and organizations at the country level, as suggested by H5. We test this hypothesis in the subsequent sections. 
Table 2. Moderating Effect of Religious Regulation: Random Slope Models

\begin{tabular}{|c|c|c|c|c|c|}
\hline & Model 2.1 & Model 2.2 & Model 2.3 & Model 2.4 & Model 2.5 \\
\hline Intercept & $\begin{array}{l}.193 \\
(135) \\
\end{array}$ & $\begin{array}{l}.167 \\
(.135) \\
\end{array}$ & $\begin{array}{l}.138 \\
(.138) \\
\end{array}$ & $\begin{array}{l}.140 \\
(.138) \\
\end{array}$ & $\begin{array}{l}.087 \\
(.142) \\
\end{array}$ \\
\hline \multicolumn{6}{|l|}{ Individual-Level Effects } \\
\hline Religious belief & $\begin{array}{l}-.020 \\
(.005) * *\end{array}$ & $\begin{array}{l}-.020 \\
(.005) * *\end{array}$ & $\begin{array}{l}-.022 \\
(.005) * *\end{array}$ & $\begin{array}{l}-.022 \\
(.005) * *\end{array}$ & $\begin{array}{l}-.022 \\
(.005) * *\end{array}$ \\
\hline Religious social behaviour & $\begin{array}{l}-.017 \\
(.017)\end{array}$ & $\begin{array}{l}.006 \\
(.013)\end{array}$ & $\begin{array}{l}.015 \\
(.005)^{* *}\end{array}$ & $\begin{array}{l}.015 \\
(.005)^{* *}\end{array}$ & $\begin{array}{l}.015 \\
(.005)^{* *}\end{array}$ \\
\hline Minority status & $\begin{array}{l}.004 \\
(.003)\end{array}$ & $\begin{array}{l}.004 \\
(.003)\end{array}$ & $\begin{array}{l}.030 \\
(.010) * *\end{array}$ & $\begin{array}{l}.016 \\
(.008)^{*}\end{array}$ & $\begin{array}{l}.022 \\
(.008) * *\end{array}$ \\
\hline \multicolumn{6}{|l|}{ Country-Level Effects } \\
\hline Pew GRI & $\begin{array}{l}-.035 \\
(.008) * * \\
\end{array}$ & - & $\begin{array}{l}-.026 \\
(.008) * * \\
\end{array}$ & - & - \\
\hline RAS religious regulation & - & $\begin{array}{l}-.006 \\
(.002)^{* * *}\end{array}$ & - & $\begin{array}{l}-.005 \\
(.002) * *\end{array}$ & - \\
\hline $\begin{array}{l}\text { RAS minority } \\
\text { discrimination }\end{array}$ & - & - & - & - & $\begin{array}{l}-.003 \\
(.001) * *\end{array}$ \\
\hline Polity score & $\begin{array}{l}.005 \\
(.004)\end{array}$ & $\begin{array}{l}.004 \\
(.005)\end{array}$ & $\begin{array}{l}.005 \\
(.004)\end{array}$ & $\begin{array}{l}.003 \\
(.005)\end{array}$ & $\begin{array}{l}.008 \\
(.004) *\end{array}$ \\
\hline $\begin{array}{l}\text { GDP per capita (PPP, } \\
\text { logged) }\end{array}$ & $\begin{array}{l}.028 \\
(.015)^{*}\end{array}$ & $\begin{array}{l}.028 \\
(.015)^{*}\end{array}$ & $\begin{array}{l}.032 \\
(.016) * *\end{array}$ & $\begin{array}{l}.030 \\
(.016) *\end{array}$ & $\begin{array}{l}.031 \\
(.016)^{*}\end{array}$ \\
\hline \multicolumn{6}{|l|}{ Cross Level Interactions } \\
\hline $\begin{array}{l}\text { Pew GRI x Religious } \\
\text { social behaviour }\end{array}$ & $\begin{array}{l}.013 \\
(.004)^{* *}\end{array}$ & - & - & - & - \\
\hline $\begin{array}{l}\text { RAS religious regulation } \mathrm{x} \\
\text { Religious social behaviour }\end{array}$ & - & $\begin{array}{l}.002 \\
(.001)^{*}\end{array}$ & - & - & - \\
\hline Pew GRI x Minority status & - & - & $\begin{array}{l}-.008 \\
(.003)^{* *}\end{array}$ & - & - \\
\hline $\begin{array}{l}\text { RAS religious regulation } \mathrm{x} \\
\text { Minority status }\end{array}$ & - & - & - & $\begin{array}{l}-.001 \\
(.001)\end{array}$ & - \\
\hline $\begin{array}{l}\text { RAS minority } \\
\text { discrimination x Minority } \\
\text { status }\end{array}$ & - & - & - & - & $\begin{array}{l}-.001 \\
(.000)^{* *}\end{array}$ \\
\hline \multicolumn{6}{|l|}{ Variance Components } \\
\hline Random intercept variance & $\begin{array}{l}.062 \\
(.008) * *\end{array}$ & $\begin{array}{l}.066 \\
(.008) * *\end{array}$ & $\begin{array}{l}.031 \\
(.006) * *\end{array}$ & $\begin{array}{l}.034 \\
(.006) * *\end{array}$ & $\begin{array}{l}.032 \\
(.006) * *\end{array}$ \\
\hline Residual variance & $\begin{array}{l}.109 \\
(.010) * *\end{array}$ & $\begin{array}{l}.111 \\
(.010) * *\end{array}$ & $\begin{array}{l}.107 \\
(.010) * *\end{array}$ & $\begin{array}{l}.106 \\
(.010) * *\end{array}$ & $\begin{array}{l}.111 \\
(.010) * *\end{array}$ \\
\hline \multicolumn{6}{|l|}{ Model Fit Indices } \\
\hline Wald $\mathrm{Chi}^{2}$ & 7386.01 & 7374.79 & 7400.78 & 7382.44 & 7386.05 \\
\hline$-2 \times$ Log Likelihood & -228.52 & -224.24 & -164.63 & -158.87 & -160.16 \\
\hline N. Level-1 Units & 53430 & 53430 & 53430 & 53430 & 53430 \\
\hline N. Level-2 Units & 58 & 58 & 58 & 58 & 58 \\
\hline
\end{tabular}

Non-standardized coefficients with standard errors in parentheses. * $p<0.1$ (two-tailed), ** $p<0.05$ (two-tailed). Models include religious belonging dummies as well as the rest of the individual-level control variables: gender, age, education dummies, income, associational membership, ideology, life satisfaction, satisfaction with household financial situation, interpersonal trust, and interest in politics. 
Main effects of religious regulation on protest. Models 1.2 through 1.5 also provide strong empirical evidence in favor of $\mathrm{H} 3$, which states that religious regulation reduces overall protest tendency. Both measures of religious regulation had negative and statistically significant effects on political protest, indicating that higher levels of religious regulation are associated with reduced levels of protest. Furthermore, these effects remained robust after controlling for the effects of level of democracy and economic development (Models 1.4 and 1.5). The expected reduction in political participation between the least and most regulated religious markets in the dataset was calculated as 22 percent for Model 1.4, and 26 percent for Model 1.5, when holding all other individual and country-level variables constant, suggesting that religious regulation variables have substantive effects on individual tendency to protest. Regarding the country-level control variables, in line with Basedau et al. (2017), the Polity variable had no statistically-significant effects on tendency to protest whereas GDP per capita had positive but statistically weak effects $(\mathrm{p}=.055$ for Model 1.4 and $\mathrm{p}=.059$ for Model 1.5; see Dalton et al., 2010 for similar findings). Note that using Freedom House scores instead of Polity measures did not change any of the results presented in Tables 1 and 2, although Freedom House scores had statistically significant effects in some models. ${ }^{9}$

The moderating effect of religious regulation and minority discrimination. Next, we tested the hypotheses concerning the moderating effect of religious regulation by specifying cross-level interactions between the two alternative regulation measures and religious social behavior (Models 2.1 and 2.2 in Table 2), and minority status (Models 2.3, 2.4 in Table 2), as well as interactions between minority discrimination and minority status (Model 2.5 in Table 2). Models 2.1 and 2.2 provide a test of $\mathrm{H} 4$, which predicted religious regulation to weaken the positive effect of religious social behavior on political protest. The interaction terms in both Model 2.1 and 2.2 were positive and statistically significant, indicating that the positive

\footnotetext{
${ }^{9}$ These results are available from the authors.
} 
effect of religious social behavior on political protest increases as religious regulation increases. This finding is contrary to $\mathrm{H} 4$. To facilitate interpretation, we plotted the marginal effect of religious social behavior on political protest conditional on religious regulation in Figure 2 (Brambor, Clark, \& Golder, 2006). As can be seen in the figure, the predicted marginal effect of religious social behavior on political protest is positive and statistically significant for higher values of the Pew GRI (right-hand side of Figure 2), and positive and statistically significant for most values of the RAS religious regulation measure, as predicted by H1. However, this positive effect becomes stronger as levels of religious regulation increase, which runs counter to our expectations.

Figure 2. Moderating Effect of Religious Regulation on Religious Social Behavior: Marginal Effect Plots with 95\% Confidence Intervals (Models 2.1 and 2.2)
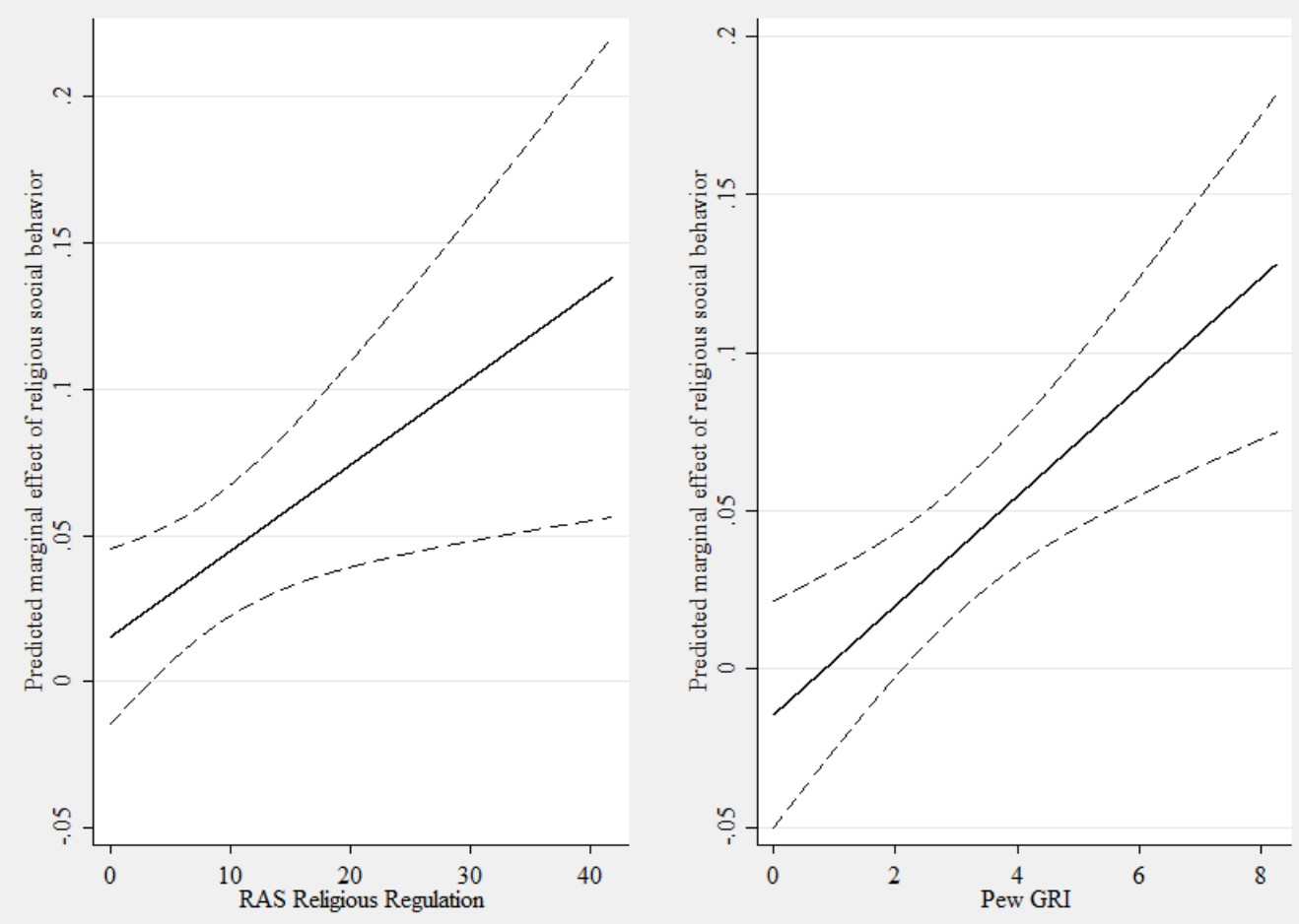
We see two possible explanations for these unexpected findings, yet only one of them could be tested with WVS data. First, based on Gurr's theory on minority mobilization, one may expect minorities to develop more grievances as religious regulation increases, which may result in greater mobilization among them (Gurr 1993, 2000). Accordingly, we tested whether the unexpected finding could be due to the majority-minority status of respondents by adding three-way interactions between religious regulation, religious social behavior, and minority status to the regressions. Online Appendix 6 presents the full results. We found that for both majority and minority respondents, the positive effect of religious social behavior on political protest became stronger as religious regulation increased, and that this effect was particularly higher for religious majorities rather than minorities. That is, the unexpected finding was not due to the majority-minority status of respondents.

A second potential explanation concerns the nature of religious involvement in high regulation contexts. Religious regulation, among other things, raises barriers to religious social activities (Sarkissian, 2015). Under high levels of religious regulation, people have fewer incentives and opportunities to participate in religious networks or collective prayers (Finke \& Stark, 2000; Wickham, 2002). In fact, even taking part in religious organizations may carry risk of persecution in highly regulated and restricted contexts (Sarkissian, 2015). In such settings where religious social behaviour is a high-risk activity, those who are willing to become active in the religious community might be individuals who already have a particularly higher propensity for political protest. Thus, people who are active in religious social networks in high regulation environments might be more willing and motivated to join political protests than those who members of such communities in deregulated contexts. Unfortunately, we are unable to test this hypothesis due to the absence of any indicators that capture risk-taking potential. 
Models $2.3-2.5$ provide a test of $\mathrm{H} 5$, which predicted minority status to decrease political protest as religious regulation increases. The interaction of minority status with the Pew GRI measure (Model 2.3) was negative and statistically significant, as expected. When the RAS religious regulation measure was used, the interaction coefficient was negative but statistically null (Model 2.4). This could be because the Pew GRI measure includes components of minority discrimination while the RAS regulation measure captures the extent of religious regulation and restrictions for all religions. In fact, Model 2.5 tested for the conditional effect of RAS minority discrimination on minority status and found a negative and statistically significant interaction coefficient. We plotted the marginal effects of minority status on political protest for levels of Pew GRI (Model 2.3) and RAS minority discrimination (Model 2.5) in Figure 3. As can be seen from both the left and right panels of the figure, minority status reduces tendency to protest as religious regulation and minority discrimination increases. Minority status has a positive effect on political protest when regulation and minority discrimination are at their lowest levels; that is, when the religious market is unregulated. The positive effect of minority status on political protest becomes indistinguishable from zero between medium and relatively high levels of regulation and minority discrimination. At the highest levels of regulation and discrimination, minority status has a negative effect on political protest. These results provide strong empirical evidence in favor of $\mathrm{H} 5$, which predicted religious regulation to decrease the likelihood of protest among religious minorities. 
Figure 3: Moderating Effect of Pew GRI and RAS Minority Discrimination on Minority Status: Marginal Effect Plots with 95\% Confidence Intervals (Models 2.3 and 2.5)
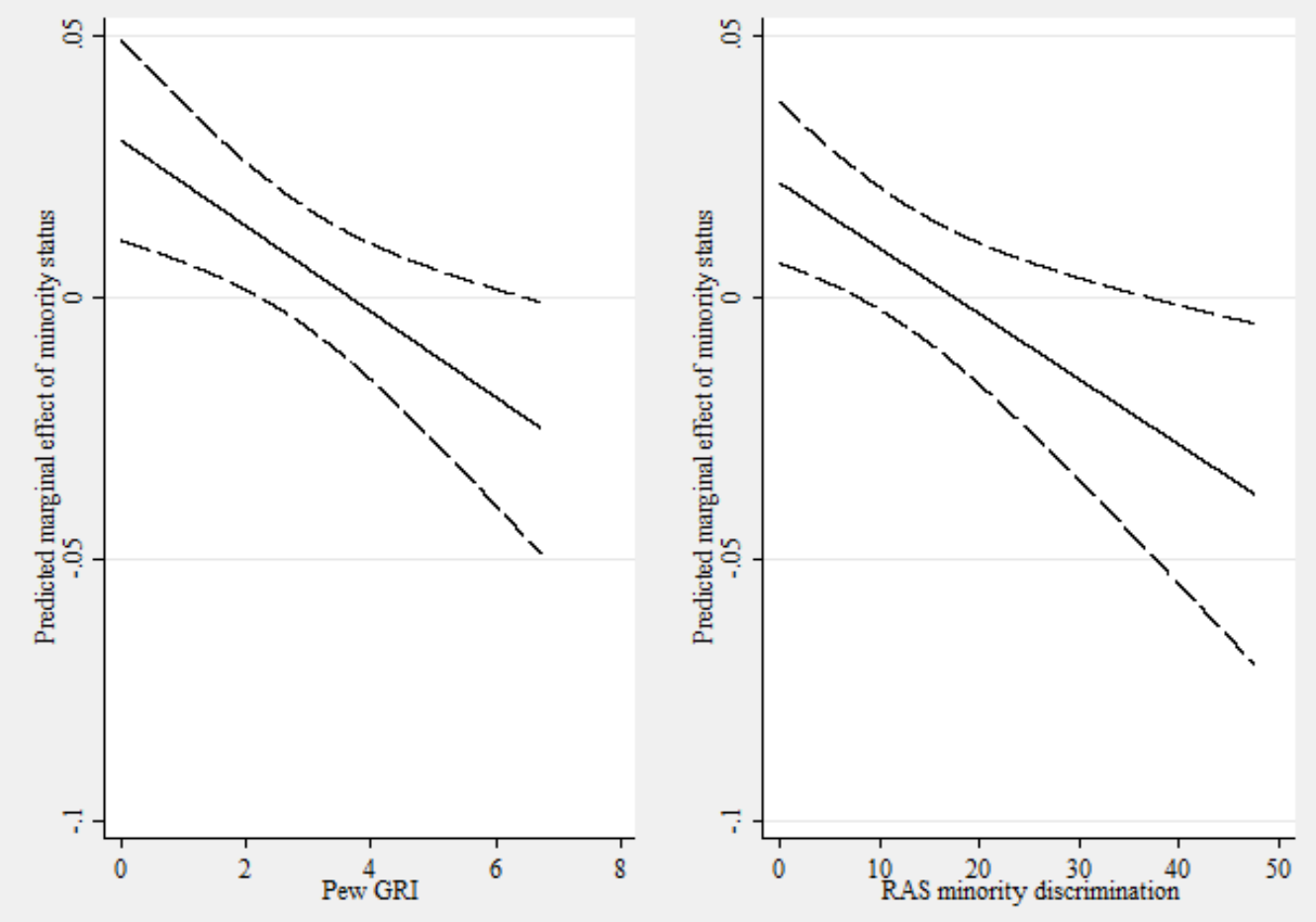

These findings provide strong evidence for the substantive effect of religious context on minority mobilization and highlight the importance of system-level openness in enabling all citizens, but especially disadvantaged groups, to participate in political protest. High levels of regulation and discrimination not only deter political protest in general (cf. Basedau et al., 2017; Fox et al., 2017) but also play a significant role in preventing minorities from becoming engaged in collective political actions, which further serves to preserve the status quo. These results are in line with recent studies rejecting a direct link between discrimination, grievances, and minority political activism (Basedau et al., 2017; Fox et al., 2017), and with 
previous research findings that increased discrimination against minorities reduces political protest by minority religious groups (Akbaba \& Taydas, 2011).

\section{Robust Analyses}

Alternative dimensions of the religious market. Although our choice of religious regulation measures as indicators of religious competition is in line with a vast literature (e.g. Chaves \& Cann, 1992; Chaves, Schraeder, \& Sprindys, 1994; Fox \& Tabory, 2008; Grim \& Finke, 2007), we also examined the robustness of our findings to alternative indicators of religious market structure. First, we tested for the effects of government support or favoritism of religion, religious diversity, and major religious denomination on political protest, and found that the results were generally in line with our expectations, and that religious regulation measures have the most robust effects on political protest (for full discussion, see Online Appendix 7). Second, we ran the interactive models in Table 2 with alternative measures of religious market structure. These results mostly replicated the findings in Table 2, providing further support for our argument. Full results and discussion are provided in Online Appendix 8.

The conditional effect of religious belief. Our approach emphasized the role of individual resources in turning demands and grievances into protest, and we did not expect the effect of religious belief on protest to be moderated by religious regulation. Nevertheless, some arguments can be made to expect government regulation to either weaken (Nepstad \& Williams, 2008) or strengthen (Hoffman \& Jamal, 2014) the negative effect of religious belief on protest. For completeness sake, Online Appendix 9 examines and reports models that consider the potential moderating effect of religious regulation and other religious context variables on religious belief and political protest. Overall, these models yielded inconsistent results so that we were unable to provide empirical evidence in favor of the conditional effect 
of religious regulation on religious belief and political protest. These results are also consistent with the resource mobilization approach to individual religiosity.

Additional control variables. In order to keep the presentation of results parsimonious and to prevent losing too many observations due to listwise deletion, we limited the number of control variables in Tables 1 and 2. Nevertheless, all the results presented in these tables are robust to the inclusion of additional control variables such as post-materialist values, confidence in institutions, and support for democracy. The full results are presented in Online Appendix 10.

Alternative coding of the minority status variable. When coding the minority status variable, we had to take a number of decisions. For example, respondents who identified with the religious tradition that had the most adherents in a country were coded as having majority status while the rest were coded as the minority. This procedure meant that being coded as the majority did not necessarily mean that the respondent's affiliated religion enjoyed majority status in the population. In addition, we did not include the unaffiliated among the religious minority. That is, respondents who were not affiliated with any major religious tradition were not counted as belonging minority religious tradition. This is why, we tested whether different coding procedures for the minority variable resulted in any substantive changes in results. Our analyses showed that the results found in Tables 1 and 2 were retained when using alternative procedures to code the minority status variable. Online Appendices 11 and 12 present a more detailed discussion and the results of these analyses.

Alternative coding of protest variable. When constructing the protest index, we assigned a score of 0.5 to respondents who reported that they might engage in a particular action. Similar to some scholars (Welzel \& Deutsch, 2012), we reasoned that this indicated a stronger tendency than completely refusing to partake in an action. Alternatively, some others suggest building the protest index using dichotomized versions of the items, such that only 
those who reported having engaged in an action receive a score of 1 while those who opt for the other two categories receive a score of 0 (Dalton et al., 2010; Norris, 2002; Vráblíková, 2016). As a robustness check, we created a version of the index using only the dichotomized versions of the variables. This index was very highly correlated with the one that we used for the subsequent analyses $(\mathrm{r}=0.81)$ and produced very similar results to those reported in Tables 1 and 2 but were statistically weaker, which is in line with the findings reported by Welzel and Deutsch (2012, p. 470). Online Appendix 13 presents full results from this analysis.

In addition, measuring protest participation may be problematic in authoritarian contexts as respondents may not reveal their true behavior. Following the previous literature (e.g. Welzel \& Deutsch, 2012:470), our protest measure included a "might do" category that could also capture those individuals who might not have been willing to admit past participation in protest but still wanted to provide a close enough answer. Of course, it is also possible that respondents in such contexts may still be hesitant to use the "might do" category. Given that there is no easy test or fix to the social desirability effects in survey questions, we opted for a sensitivity analysis by running Models 1.4 and 1.5 in Table 1 but excluding countries with a Polity IV score lower than 0 (autocracies and closed anocracies). If there were a systematic measurement error in the dependent variable for non-democratic countries that leads to a bias in the regression estimates then we would expect to observe changes in the direction and/or standard errors of the coefficients when these non-democratic countries are excluded from the models. We found that both individual and country level coefficients remained unchanged in models with only democratic countries in the dataset. Full results are presented in Online Appendix 14. These results provide further evidence for the robustness of our findings. 


\section{Conclusion}

Religion possesses assets for both bolstering and challenging the legitimacy of governments. On the one hand, religious people generally follow moral instructions to respect authority and preserve traditions (Graham \& Haidt, 2010). On the other hand, religious symbols and identities are at the core of some of the most impressive examples of political protest, such as the Arab Spring, the civil rights movement in the United States, or the Solidarity movement in Poland. This study contributes to the debate about the differential role of religion in political protest by offering a theoretical framework that accounts for the effects of individual-level resources and system-level opportunities and their interactions. Unlike most studies in the field, our results are based on cross-national data from a large number of countries that are highly diverse in terms of levels of democracy, development, and religious context, which enhances the generalizability of our findings.

Our results make several contributions to the literature. First, they highlight the importance of system-level opportunities provided by religious markets on individual tendency to protest, showing that religion can be a significant source of political activism when religious organizations are free to compete with each other. The effect of religious deregulation holds when controlling for levels of democracy, which suggests that, in addition to overall levels of system openness, the freedoms and autonomy granted to religious institutions are also crucial in facilitating protest behavior. Religious deregulation and autonomy are especially crucial for religious minorities. In line with our expectations, we found that the protest potential of religious minorities is conditional on the level of religious freedoms in a country. Higher levels of government intervention in religious markets in general and targeted discrimination against minority groups in particular lead minorities to protest less than those belonging to a country's majority tradition, which serves to further maintain the existing inequalities between religious groups. 
Second, while earlier studies found that religious regulation heightens religious extremism, religious conflicts, and violence (Akbaba \& Taydas, 2011; Grim \& Finke, 2007; Finke, 2013; Muchlinski, 2014; Philpott, 2007), we found that regulation decreases peaceful protest by minority groups. These results seem to complement each other in that, if high levels of religious regulation and religious discrimination deter religious minorities from using peaceful protest to achieve their goals then they may become more willing to resort to violence. While our findings provide only partial evidence for this, more research is necessary to provide evidence to test this causal chain.

Third, our findings indicate that religious belief generally has a system-justifying function. However, the finding that religious belief generally reduces individual tendency to protest should not lead to the conclusion that religiously-based values or ideas will not inspire political protest at all. We suggest that religious beliefs may have the potential to influence political protest, but this would depend on the interpretation of religious teachings and texts by religious leaders in a way that inspires collective political action. The interpretation of faiths and religious texts varies across time and context (Sandal, 2012), such that the same faith systems may be used to both justify and denounce cooperation and peace (Fox, 2002), and religious organizations and leaders may adopt different theologies across time that may suppress or inspire political activity (Philpott, 2007). Future research can further examine how and why religious leaders prefer to interpret teachings in a way that encourages political protest.

Next, while our findings were mostly in line with our initial expectations, the analysis also showed that, unexpectedly, religious regulation increases the protest potential of those already engaged in religious social activities. In general, in highly regulated contexts, involvement in religious social activities carry greater risks and it is possible that those who participate in such activities in such contexts are more risk-taking or devoted to communal 
causes than those who participate in such activities in less regulated religious markets. Future research could look into the differential motivations and psychological correlates of religious social behavior in different contexts and its implications for political behavior, including but not limited to political protest.

Finally, our findings highlight the complex role of religion in motivating protest behavior, suggesting that a full understanding of this relationship requires a careful examination of several levels of analysis. Religion is a set of beliefs and institutions embedded in a broader cultural and political context. As such, its effects on political behavior in general and political protest more specifically, are shaped by both the characteristics of the devout and their connections with their religious community and religious organizations. Given that these various aspects have differential effects on political behavior, future studies of religion and protest should consider more than a single element of religiosity by including personal and group layers as well as the broader social context. 


\section{References}

Akbaba, Y., \& Taydas, Z. (2011). Does religious discrimination promote dissent? A quantitative analysis. Ethnopolitics, 10(3-4), 271-295.

Barro, R. J. (2003). Religion adherence data. Retrieved from http://scholar.harvard.edu/barro/publications/religion-adherence-data. (Accessed $6 / 22 / 2015)$.

Basedau, M., Fox, J., Pierskalla, J.H., Strüver, G., \& Vüllers, J. (2017). Does discrimination breed grievances -and do grievances breed violence? New evidence from an analysis of religious minorities in developing countries. Conflict Management and Peace Science, 34(3), 217-239.

Ben-Nun Bloom, P. (2016). State level restriction of religious freedom and women's rights: A global analysis. Political Studies, 64(4), 811-831.

Ben-Nun Bloom, P., \& Arikan, G. (2012). A two-edged sword: The differential effect of religious belief and religious social context on attitudes towards democracy. Political Behavior, 34(2), 249-276.

Ben-Nun Bloom, P., \& Arikan, G. (2013). Religion and support for democracy: A crossnational test of the mediating mechanisms. British Journal of Political Science, 43(2), $375-397$.

Ben-Nun Bloom, P., Arikan, G., \& Courtemanche, M. (2015). Religious social identity, religious belief, and anti-immigration sentiment. American Political Science Review, 109(2), 203-221.

Ben-Nun Bloom, P., Arikan, G., \& Sommer, U. (2014). Globalization, threat and religious freedom. Political Studies, 62(2), 273-291.

Bobo, L., \& Gilliam, F.D. 1990. Race, sociopolitical participation, and black empowerment. American Political Science Review, 84(2), 377-393. 
Bohannon, J. (2016). Turkish scholar who eluded arrest describes 'witch hunt'. Science, 351(6280), 1381.

Brambor, T., Clark, W. R., \& Golder, M. (2006). Understanding interaction models: improving empirical analyses. Political Analysis, 14(1), 63-82.

Chaves, M., \& Cann, D.E. (1992). Regulation, pluralism, and religious market structure: Explaining religion's vitality. Rationality and Society, 4(3), 272-290.

Chaves, M., Schraeder, P.J., \& Sprindys, M. (1994). State regulation of religion and Muslim religious vitality in the industrialized West. The Journal of Politics, 56, 1087-1097.

Collins, K. (2007). Ideas, networks, and Islamist movements: Evidence from Central Asia and the Caucasus. World Politics, 60(1), 64-96.

Dalton, R., van Sickle, A., \& Weldon, S. (2010). The individual-institutional nexus of protest behavior. British Journal of Political Science, 40(1), 51-73.

Djupe, P. A., \& Gilbert, C. P. (2006). The resourceful believer: generating civic skills in church. The Journal of Politics, 68(1), 116-127.

Djupe, P. A., \& Gilbert, C. P. (2009). The political influence of churches. Cambridge: Cambridge University Press.

Djupe, P. A., \& Grant, J. T. (2001). Religious institutions and political participation in America." Journal for the Scientific Study of Religion, 40(2), 303-314.

Eisinger, P. K. (1973). The conditions of protest behavior in American cities. American Political Science Review, 67(01), 11-28.

Finke, R. (2013). Presidential address origins and consequences of religious freedoms: A global overview. Sociology of Religion, 74(3), 297-313.

Finke, R., \& Stark, R. (1988). Religious economies and sacred canopies. American Sociological Review, 53(1), 41-49. 
Fox, J. (2002). Ethnoreligious conflict in the late twentieth century: A general theory. Lanham, Md.: Lexington.

Fox, J. (2004). Religion, civilization and civil war: 1945 through the new millennium. Lanham, MD: Lexington Books.

Fox, J. (2015). Political secularism, religion, and the state: A time series analysis of worldwide data. New York, NY: Cambridge University Press.

Fox, J. (2016). Secular-religious competition in Western democracies: 1990 to 2014. Journal of Religious and Political Practice, 2(2), 155-174.

Fox, J., Bader, C., \& McClure, J.M. (2017). Don't get mad: The disconnect between religious discrimination and individual perceptions of government. Conflict Management and Peace Science. Forthcoming. DOI: 10.1177/0738894217723160.

Fox, J., \& Tabory, E. (2008). Contemporary evidence regarding the impact of state regulation of religion on religious participation and belief. Sociology of Religion, 69(3), 245-271.

Gill, A. (1998). Rendering unto Caesar: The Catholic Church and the state in Latin America. Chicago: University of Chicago Press.

Gill, A. (2008). The political origins of religious liberty. New York: Cambridge University Press.

Graham, J., \& Haidt, J. (2010). Beyond beliefs: Religions bind individuals into moral communities. Personality and Social Psychology Review, 14(1), 140-150.

Grim, B. J., \& Finke, R. (2006). International religion indexes: Government regulation, government favoritism, and social regulation of religion. Interdisciplinary Journal of Research on Religion, 2(1), 1-40.

Grim, B. J., \& Finke, R. (2007). Religious persecution in cross-national context: Clashing civilizations or regulated religious economies? American Sociological Review, 72(4), $633-658$. 
Grzymala-Busse, A. (2012). Why comparative politics should take religion (more) seriously. Annual Review of Political Science, 15(1), 421-442.

Gurr, T. R. (1993). Minorities at risk: A global view of ethnopolitical conflicts. Washington, DC: United States Institute of Peace Press.

Gurr, T. R. (2000). Peoples versus states: Minorities at risk in the new century. Washington, DC: United States Institute of Peace Press.

Helbling, M., \& Traunmüller, R. (2016). How state support of religion shapes attitudes toward Muslim immigrants: New evidence from a sub-national comparison. Comparative Political Studies, 49(3), 391-424.

Hoffman, M. T., \& Jamal, A. (2014). Religion in the Arab spring: Between two competing narratives. The Journal of Politics, 76(3), 593-606.

Hoffman, M. T., \& Nugent, E. R. (2017). Communal religious practice and support for armed parties: Evidence from Lebanon. Journal of Conflict Resolution, 61(4), 869-902.

Iannaconne, L. R. (1991). The consequences of religious market structure: Adam Smith and the economics of religion. Rationality and Society, 3(2), 156-177.

Isaacs, M. 2017. Faith in contention. Explaining the salience of religion in ethnic conflict. Comparative Political Studies, 50(2), 200-231.

Jamal, A. (2005). The political participation and engagement of Muslim Americans: Mosque involvement and group consciousness. American Politics Research, 33(4), 521-544.

Jelen, T. G., \& Wilcox, C. C. (2002). Introduction: the one and the many - religion and politics in comparative perspective. In T. Jelen \& C. Wilcox (Eds.), Religion and politics in comparative perspective: The one, the few, and the many (pp. 1-26). New York: Cambridge University Press.

Jost, J. T., Hawkins, C. B., Nosek, B. A., Hennes, E.P., Stern, C., Gosling, S.D., \& Graham, J. (2014). Belief in a just god (and a just society): A system justification perspective on 
religious ideology. Journal of Theoretical and Philosophical Psychology, 34(1), 5681.

Klandermans, B. (1984). Mobilization and participation: Social-psychological expansions of resource mobilization theory. American Sociological Review, 49(5), 583-600.

Layman, G. (2001). The great divide: Religious and cultural conflict in American party politics. New York: Columbia University Press.

Marien, S., Hooghe, M., \& Quintelier, E. (2010). Inequalities in non-institutionalized forms of political participation: A multi-level analysis of 25 countries. Political Studies, 58(1), 187-213.

McCarthy, J.D., \& Zald, M.N. (1977). Resource mobilization and social movements: A partial theory. American Journal of Sociology, 82(6), 1212-1241.

McClarendon, G., \& Riedl, R.B. (2015). Religion as a stimulant for political participation: Experimental evidence from Nairobi, Kenya. The Journal of Politics, 77(4), 10451057.

McVeigh, R., \& Sikkink, D. (2001). God, politics, and protest: Religious beliefs and the legitimation of contentious tactics. Social Forces, 79(4), 1425-1458.

Meyer, D. S. (2004). Protest and political opportunities. Annual Review of Sociology, 30(1), $125-145$.

Muchlinski, D. (2014). Grievances and opportunities: Religious violence across political regimes. Politics and Religion, 7(4), 684-705.

Nepstad, S. E., \& Williams, R. H. (2008). Religion in rebellion, resistance and social movements. In J. A. Beckford, \& J. Demerath (Eds), Sage handbook of the sociology of religion (pp. 419-437). Thousand Oaks: Sage.

Norris, P. (2002). Democratic phoenix: Reinventing political activism. Cambridge: New York: Cambridge University Press. 
Norris, P., \& Inglehart, R. (2004). Sacred and secular: Religion and politics worldwide. Cambridge: Cambridge University Press.

Olson, M. (1965). The logic of collective action: Public goods and the theory of groups. Cambridge, MA: Harvard University Press.

Peterson, S. A. (1992). Church participation and political participation: The spillover effect. American Politics Research, 20(1), 123-139.

Philpott, D. (2007). Explaining the political ambivalence of religion. American Political Science Review, 101(3), 505-525.

Putnam, R. D. (2000). Bowling alone: The collapse and revival of American community. New York: Simon \& Schuster.

Sandal, N.A. (2012). The clash of public theologies?: Rethinking the concept of religion in global politics. Alternatives, 37, 66-83.

Sarkissian, A. (2015). The varieties of religious repression: Why governments restrict religion. New York, NY: Oxford University Press.

Saroglou, V., Delpierre, V., \& Dernelle, R. (2004). Values and religiosity: A meta-analysis of studies using Schwartz's model. Personality and Individual Differences, 37, 721-734.

Scheufele, D. A., Nisbet, M. C., \& Brossard, D. (2003). Pathways to political participation? Religion, communication contexts, and mass media. International Journal of Public Opinion Research, 15(3), 300-324.

Schwartz, S.H. (2007). Value orientations: Measurement, antecedents and consequences across nations. In R. Jowell, C. Roberts, R. Fitzgerald \& G. Eva (Eds), Measuring attitudes cross-nationally: Lessons from the European Social Survey (pp. 161-193). London: Sage.

Smidt, C. E., Kellstedt, L. A., \& Guth, J. L. (2009). The role of religion in American politics: Explanatory theories and associated analytical and measurement issues. In C. Smidt, 
L. A. Kellstedt, \& J. L. Guth (Eds.), Oxford handbook on religion and American politics (pp. 3-42). Oxford: Oxford University Press.

Stark, R., \& Finke, R. (1988). American religion in 1776: A statistical portrait. Sociological Analysis, 49(1), 39-51.

Stark, R., \& Finke, R. (2000). Acts of faith: Explaining the human side of religion. Berkeley, CA: University of California Press.

Stark, R., \& Iannaccone, L. R. (1994). A supply-side reinterpretation of the "secularization" of Europe. Journal for the Scientific Study of Religion, 33 (3), 230-252.

Steenbergen, M., \& Jones, B. S. (2002). Modeling multilevel data structures. American Journal of Political Science, 46(1), 218-237.

Tarrow, S. G. (1994). Power in movement: Social movements, collective action and politics. Cambridge and New York: Cambridge University Press.

Tilly, C. (1978). From mobilization to revolution. Reading, MA: Addison-Wesley.

Trejo, G. (2009). Religious competition and ethnic mobilization in Latin America: Why the Catholic Church promotes indigenous movements in Mexico. American Political Science Review, 103(3), 323-342.

Van de Vijver, F. J. R. (2003). Bias and equivalence: Cross-cultural perspectives. In J. A. Harkness, F. J. R. Van de Vijver, \& P. P. Mohler (Eds.), Cross-cultural survey methods (pp. 143-155). Hoboken, NJ: John Wiley \& Sons, Inc.

Verba, S., Norman H. N., \& Kim, J. (1978). Participation and political equality: A sevennation comparison. New York and London: Cambridge University Press.

Voicu, M. 2012. Effect of nationalism on religiosity in 30 European countries. European Sociological Review, 28(3), 333-343. 
Vráblíková, K. (2016). How context matters? Mobilization, political opportunity structures, and nonelectoral political participation in old and new democracies. Comparative Political Studies, 47(2), 203-229.

Wald, K. D., Silverman, A. L., \& Fridy, K. S. (2005). Making sense of religion in public life. Annual Review of Political Science, 8(1), 121-143.

Wald, K. D., \& Wilcox, C. (2006). Getting religion: Has political science rediscovered the faith factor? American Political Science Review, 100(4), 523-529.

Welzel, C., \& Deutsch, F. (2012). Emancipative values and nonviolent protest: The importance of "ecological” effects. British Journal of Political Science, 42(2), 465479.

Wickham, C.R. (2002). Mobilizing Islam: Religion, activism and political change in Egypt. New York: Columbia University Press. 